\title{
Influence of thermodynamic parameters on the genotoxicity of bioactive phenolic compounds present in food
}

Estela Guardado Yordi, ${ }^{1,2 *}$ Maria João Matos, ${ }^{2}$ Lourdes Santana, ${ }^{2}$ Eugenio Uriarte, ${ }^{2}$ Enrique Molina Pérez 3,4

${ }^{1}$ Universidad de Camagüey "Ignacio Agramonte Loynaz”, Facultad de Química, Departamento de Ciencia y Tecnología de los alimentos, Camagüey - Cuba; estela.guardado@reduc.edu.cu

${ }^{2}$ Universidad de Santiago de Compostela, Facultad de Farmacia, Departamento de Química Orgánica, Santiago de Compostela - España; mariacmatos@gmail.com lourdes.santana@usc.es eugenio.uriarte@usc.es

${ }^{3}$ Universidad de Camagüey "Ignacio Agramonte Loynaz”, Facultad de Química, Departamento de Química, Camagüey - Cuba; enrique.molina@reduc.edu.cu

${ }^{4}$ Universidade do Estado do Amazonas, Centro de Estudos Superiores de Parintins. Estrada Odovaldo Novo, s/n, Djard Vieira. Parintins, Amazonas - Brasil

\begin{abstract}
The effects in health of food rich in phenols require currently studies related to safety. It has been shown that these compounds can present dual activity (antioxidant/pro-oxidant effects). In this sense, this work it is focused on an in silico study to determine the relationships of various thermodynamic parameters to genotoxicity (GT) of phenolic compounds: flavonoids, cinnamic acids and coumarins. The fundamental basis of the extra-thermodynamic methodology establishes that the structure of the bioactive molecule is a function of certain local and global properties. It was modeled the influence of local and global parameters that characterize the structure (hydrophobic, steric, electronic, and $\log \mathrm{P}$ properties) relative to the clastogenic capacity (chromosome aberration generated by DNA damage due to its pro-oxidant activity). To achieve these objectives they were used ChemDraw, MODESLAB and STATISTIC software. They were identified properties influencing the genetic damage caused by the studied compounds with pro-oxidant activity, expressed through different Multivariate Linear
\end{abstract}


Regression (MLR) statistical models. It was shown that steric (Sterimol, L) and hydrophobic $(\pi)$ properties presented greater influence than the electronic properties (Hammett constant, $\sigma^{*}$ ). Regarding the global property analysed, it was found that a decrease in the $\log \mathrm{P}$ is associated with increased DNA damage by clastogenicity. The results allow us to produce an analysis of structure-toxicity relationship in designing strategies for nutraceuticals, functional foods and novel drug with such phenolic compounds on their structure.

Keywords: Thermodynamic parameters, genotoxicity, phenolic compounds, MODESLAB, functional food.

\section{Introduction}

Phenolic compounds derived from the secondary metabolism of plants, and are present in different types of foods. They are xenobiotics that are ingested as part of the diet. Recently they are being widely studied because of their different benefits to human health, such as antioxidant activity. This activity has been well documented. However, it has also been evidenced that many of these substances have pro-oxidant activity in various experimental systems, under certain conditions, such as high dosage or the presence of metal ions [1-4]. Studies in recent decades, about this duality, have been carried out primarily in vitro. However, today it is known for example, that the in vivo efficacy of the antioxidant activity of flavonoids is less documented than their in vivo pro-oxidant properties [5]. Such results lead to the necessity of continued studies to evaluate the flavonoids from the point of view of their possible "adverse effect" (according to the purpose of use), which is of particular attention during the design and development of new types of food: additives, functional foods, nutraceuticals and even drugs. It is known that some of these phenolic substances can be genetically active, and therefore capable of interacting with genetic material (DNA) [6]. These effects could be related to injuries that can take years to manifest, although there is a relationship between exposure to genotoxic substances either occupational, accidental or due lifestyles, and increased risk of cancer [7]. The potential exposure to genotoxic agents, both physical and chemical, can produce, depending on the type of injury induced on DNA, chromosomal abnormalities such as chromosomal and/or aberrations, making these agents clastogens $[8,9]$. DNA damage is an indicator of exposure to agents that affect it, and it is commonly measured by the breakage of single or double chains as 
chromosomal aberrations $[10,11]$. The latter are easily observed by structural changes in the metaphase of the cell cycle, which are caused by breakage (clastogenic processes) of unrepaired or poorly repaired DNA chains [12]. This process is considered endpoints of oxidative damage to DNA, in conjunction with mutations [6]. There are reports of phenolic substances with clastogenic activity. It has also been predicted by in silico studies that some substances reported to have pro-oxidant activity can be clastogenic $[13,14]$.

In order to predict the clastogenic activity of phenolic compounds with reported pro-oxidant activity, QSAR methods have been employed $[13,14]$ and they have been interpreted, in structural terms, structure-activity relationships. This has allowed the identification of structural alerts associated with clastogenic activity using the TOPSMODE approach. It has been reported the influence of different substituents on polyphenolic congeneric structures, in a topological substructural level. Research has allowed us to appreciate a possible relationship between $\log \mathrm{P}$ and clastogenic activity.

The fundamentals of extrathermodynamic methodology $[15,16]$ can be formalized in a number of areas, including: (i) biological activity is a function of the structure of the drug, (ii) a structure of the drug entails certain overall properties such as hydrophobicity, net charge, solubility, etc.. and certain local properties as distribution of hydrophobicity, charge and volume, in certain positions of the molecule, (iii) these global and local properties can be quantified through molecular or fragmental parameters, and (iv) there is always a function relating changes in biological activity with changes in the local and global properties, while this may not be simple nor obvious.

Correlations may be established between the biological activity and a linear combination of indexes (parameters) representing the physical and chemical changes within a series of molecules.

The parameters can be classified as: (i) molecular, regarding to the entire molecule, for example $\log \mathrm{P}$ (partition coefficient), RM (molar refractivity), $\mu \mathrm{D}$ (dipolar moment), (ii) fragmental, related to the contribution of a fragment or substituent to the studied property, for example $\pi$ (hydrophobic substituent constant), $\sigma$ (Hammett constant), Es (Taft steric parameter), and (iii) other parameters that cannot be obtained experimentally, but can be obtained for example by Molecular Modelling [17], Quantum-Mechanical Calculations (HOMO and LUMO energies) and Molecular Structure (Connectivity Index and Molecular Weight) [18]. 
In order to study the influence of the hydrophobic, steric and electronic properties, the present work aims to conduct an in silico study to determine the relationship of various thermodynamic parameters to genotoxicity (GT) of phenolic compounds, including flavonoids, cinnamic acids and coumarins.

\section{Materials and methods}

It was used a model of clastogenic structure-activity relationship validated and reported by Estrada et al, 2006. This model (Equation 1), explains the relationship between the chemical structure and clastogenicity and coded topological information in each spectral moment $(\mu)$ bond weight (molecular descriptors). The MODESLAB program calculated the global spectral moments.

$$
\begin{aligned}
& \left.\left.G T=0.0091\left[\Omega\left(\mu_{1}^{P S}\right)\right]-1.5520 \times 10^{-4}\left[\Omega\left(\mu_{5}^{v d W}\right)\right]+0.148\left[\Omega\left(\mu_{4}^{C h}\right)\right]-0.0021\right] \Omega\left(\mu_{2}^{P S}\right)\right]+ \\
& +2.6261 \times 10^{-4}\left[\Omega\left(\mu_{3}^{P S}\right)\right]-3.8422 \times 10^{-5}\left[\Omega\left(\mu_{4}^{P S}\right)\right]+1.1520 \times 10^{-4}\left[\Omega\left(\mu_{4}^{M R}\right)\right]+ \\
& +1.2011 \times 10^{-6}\left[\Omega\left(\mu_{5}^{P S}\right)\right]-9.8202 \times 10^{-5}\left[\Omega\left(\mu_{5}^{M R}\right)\right]-3.8263 \times 10^{-5}\left[\Omega\left(\mu_{8}^{H}\right)\right]- \\
& -0.0626\left[\Omega\left(\mu_{2}^{P o l}\right)\right]+1.6689\left[\Omega\left(\mu_{1}^{P O l}\right)\right]-0.0078\left[\Omega\left(\mu_{5}^{C h}\right)\right]+0.1123\left[\Omega\left(\mu_{3}^{C h}\right)\right]-0.6517
\end{aligned}
$$

The $\Omega$ is used to indicate that the corresponding variable in brackets was orthogonalized respecting to the rest of the variables included in the model. The classification model obtained is given below, together with the statistical parameters of the linear discriminate of the squared analysis, where $\lambda$ is the Wilks' statistics, $D^{2}$ is the Mahalanobis distance and $F$ is the Fisher ratio (Wilks' $-\lambda=0.629 ; F(14.194)=8.148 ; D^{2}=2.353 ; \mathrm{p}<0.0000$ ).

The multivariate linear regression (MLR), for the formation of the thermodynamic models and linear discriminant analysis (LDA) for classification as active or inactive, were performed with the STATISTICA program version 4.13.

For the development of the MTE associated with local properties (MLR), the percentage of GT of the studied compounds was used. In particular, the substituents present in the compounds were studied, constituting GT the dependent variable. Overall properties were based on the properties of the substituents (local properties). 
The analysis of local thermodynamic properties was taken into account for each of the corresponding thermodynamic models, considering as independent variables: (i) principal steric parameter, Sterimol (L), (ii) hydrophobic parameter, substituent constant ( $\pi$ ) and (iii) electronic parameter, Hammett constant $\left(\sigma^{*}\right)$. The values of these parameters were considered for each of the substituents present in the tested structures. Each substituent value, for each parameter, was taken from the literature [19-21].

In the case of MTE that relates a global property to the GT, constituted the independent variables: a) dummy variable corresponding to different kinds of phenolic compounds and b) lipophilicity data employing the values of octanol/water reported by reference [22].

\section{Results and discussion}

Flavonoids are the most abundant phenolic compounds in plant foods. Coumarin compounds are reported to be present in several classes of foods, such as cinnamon, ginger bread, green tea, chicory and fruits (bilberry and cloudberry). Figure 1 shows the basic structure of the families of studied compounds.

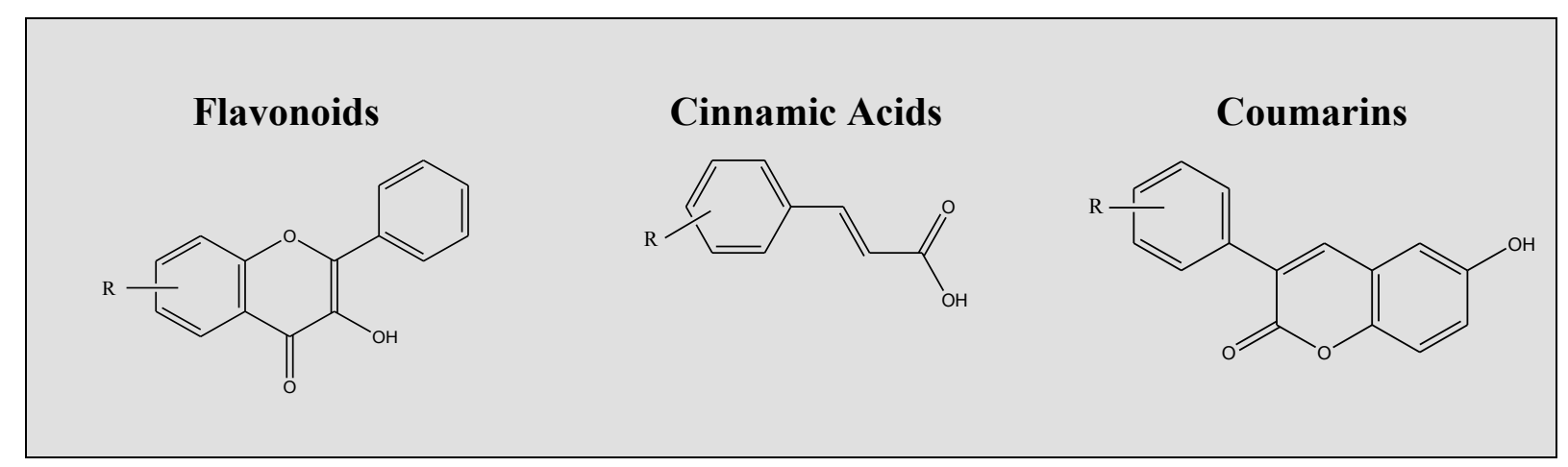

Figure 1. Basic structures of the compounds presented in this study.

In Table 1 it is shown a list of the molecules used in the study, with or without pro-oxidant reports. 
Table 1. Molecules used in the study, with or without pro-oxidant reports.

\begin{tabular}{|c|c|c|c|}
\hline Compounds $^{1}$ & CAS number ${ }^{2}$ & SMILE & References \\
\hline Quercetin & $117-39-5$ & $\begin{array}{l}\mathrm{OC} 1=\mathrm{CC} 2=\mathrm{C}(\mathrm{C}(=\mathrm{C} 1) \mathrm{O}) \mathrm{C}(=\mathrm{O}) \mathrm{C}( \\
=\mathrm{C}(\mathrm{O} 2) \mathrm{C} 3=\mathrm{CC}(=\mathrm{C}(\mathrm{O}) \mathrm{C}=\mathrm{C} 3) \mathrm{O}) \mathrm{O}\end{array}$ & [23] \\
\hline Kaempferol & $520-18-3$ & $\begin{array}{l}\mathrm{OC} 1=\mathrm{CC}=\mathrm{C}(\mathrm{C}=\mathrm{C} 1) \mathrm{C} 2=\mathrm{C}(\mathrm{O}) \mathrm{C}(= \\
\mathrm{O}) \mathrm{C} 3=\mathrm{C}(\mathrm{O} 2) \mathrm{C}=\mathrm{C}(\mathrm{O}) \mathrm{C}=\mathrm{C} 3 \mathrm{O}\end{array}$ & [23] \\
\hline Hesperetin & $520-33-2$ & & [24] \\
\hline Naringenin & $480-41-1$ & $\begin{array}{l}\mathrm{OC} 1=\mathrm{CC}=\mathrm{C}(\mathrm{C}=\mathrm{C} 1) \mathrm{C} 2 \mathrm{CC}(=\mathrm{O}) \mathrm{C} 3 \\
=\mathrm{C}(\mathrm{O} 2) \mathrm{C}=\mathrm{C}(\mathrm{O}) \mathrm{C}=\mathrm{C} 3 \mathrm{O}\end{array}$ & {$[23,24]$} \\
\hline Gallic acid & $118-41-2$ & $\begin{array}{l}\mathrm{COC} 1=\mathrm{C}(\mathrm{OC}) \mathrm{C}(=\mathrm{CC}(=\mathrm{C} 1) \mathrm{C}(\mathrm{O})= \\
\mathrm{O}) \mathrm{OC}\end{array}$ & {$[23,25-27]$} \\
\hline Caffeic acid & $331-39-5$ & $\begin{array}{l}\mathrm{OC}(=\mathrm{O}) \mathrm{C}=\mathrm{CC} 1=\mathrm{CC}=\mathrm{C}(\mathrm{O}) \mathrm{C}(=\mathrm{C} 1) \\
\mathrm{O}\end{array}$ & [23] \\
\hline 6,7-Dimethoxycoumarin & $120-08-1$ & $\mathrm{O}=\mathrm{C} 1 \mathrm{OC} 2=\mathrm{C}(\mathrm{C}=\mathrm{C}(\mathrm{OC}) \mathrm{C}(\mathrm{OC})=\mathrm{C} 2$ & [28] \\
\hline 7-Methoxycoumarin & $531-59-9$ & $\begin{array}{l}\mathrm{O}=\mathrm{C} 1 \mathrm{OC} 2=\mathrm{C}(\mathrm{C}=\mathrm{CC}(\mathrm{OC})=\mathrm{C} 2) \mathrm{C}= \\
\mathrm{C} 1\end{array}$ & [29] \\
\hline 7-Methylcoumarin & $2445-83-2$ & $\begin{array}{l}\mathrm{O}=\mathrm{C} 1 \mathrm{OC} 2=\mathrm{C}(\mathrm{C}=\mathrm{CC}(\mathrm{C})=\mathrm{C} 2) \mathrm{C}=\mathrm{C} \\
1\end{array}$ & [29] \\
\hline 6-Methylcoumarin & $92-48-8$ & $\mathrm{O}=\mathrm{C} 1 \mathrm{OC} 2=\mathrm{C}(\mathrm{C}=\mathrm{C}(\mathrm{C}) \mathrm{C}=\mathrm{C} 2) \mathrm{C}=\mathrm{C} 1$ & [29] \\
\hline Coumarin & $91-64-5$ & $\mathrm{O}=\mathrm{C} 1 \mathrm{OC} 2=\mathrm{C}(\mathrm{C}=\mathrm{CC}=\mathrm{C} 2) \mathrm{C}=\mathrm{C} 1$ & {$[28]$} \\
\hline
\end{tabular}

${ }^{1}$ Reference $[14] ;{ }^{2}$ CAS, Chemical Abstracts Service.

A summary of the $\log \mathrm{P}$ values used to prepare the model and the percentage of probability of being active predicted by the MTE (equation 1), are shown in Table 2. Of these, morin and taxifolin have no pro-oxidant report. 
Table 2. $\log$ P values and prediction of GT activity of flavonoids, phenolic acids and coumarins.

\begin{tabular}{|c|c|c|}
\hline Compounds & $\log P$ & $\begin{array}{c}\text { Probability of activity }^{2} \\
(\%)\end{array}$ \\
\hline Gallic acid & $0.91^{1}$ & +97.2 \\
\hline Caffeic acid & $2.47^{1}$ & -59.2 \\
\hline Naringenin & $2.59^{1}$ & +52.6 \\
\hline Taxifolin $^{3}$ & $1.22^{1}$ & +71.3 \\
\hline Hesperetin & $2.30^{1}$ & +85.9 \\
\hline Kaempferol & $2.69^{1}$ & +53.0 \\
\hline Morin $^{3}$ & $1.97^{1}$ & +66.5 \\
\hline Quercetin & $2.74^{1}$ & +67.6 \\
\hline 6,7-Dimethoxycoumarin & $1.9^{4}$ & +79.3 \\
\hline 7-Methoxycoumarin & - & $+60,4$ \\
\hline 7-Methylcoumarin & $1.8^{4}$ & -73.0 \\
\hline 6-Methylcoumarin & $1.85^{4}$ & -73.4 \\
\hline Coumarin & $1.39^{4}$ & -62.7 \\
\hline
\end{tabular}

${ }^{1}[22], \quad{ }^{2}$ By MTE (Equation 1), ${ }^{3}$ compounds without pro-oxidant reported activity. ${ }^{4}$ By http://www.thegoodscentscompany.com/. Negative value (no GT) and positive value (GT).

To study the local hydrophobic, steric and electronic properties, it was necessary to design new structures of flavonoids and coumarins, which were subsequently checked for their existence. Table 3 shows a summary of the studied compounds, their GT probability values and the substituents, which determined thermodynamic parameter values. Substituents values for each thermodynamic parameter were taken from Kubinyi, 1993. 
Table 3. GT activity and substituents presented in the new flavonoids and coumarins.

\begin{tabular}{|c|c|c|c|}
\hline Comp. & SMILE & Substituent & $\begin{array}{l}\text { Probability of activity } \\
\qquad(\%)^{1}\end{array}$ \\
\hline I & $\begin{array}{l}\mathrm{O}=\mathrm{C} 2 \mathrm{OC} 1=\mathrm{C}(\mathrm{O}) \mathrm{C}=\mathrm{C}(\mathrm{O}) \mathrm{C}=\mathrm{C} 1 \mathrm{C}=\mathrm{C} 2 \mathrm{C} 3=\mathrm{C} \\
\mathrm{C}=\mathrm{C}(\mathrm{CC}) \mathrm{C}=\mathrm{C} 3\end{array}$ & $\mathrm{C}_{2} \mathrm{H}_{5}$ & -65.4 \\
\hline II & $\begin{array}{l}\mathrm{O}=\mathrm{C} 2 \mathrm{OC} 1=\mathrm{C}(\mathrm{O}) \mathrm{C}=\mathrm{C}(\mathrm{O}) \mathrm{C}=\mathrm{C} 1 \mathrm{C}=\mathrm{C} 2 \mathrm{C} 3=\mathrm{C} \\
\mathrm{C}=\mathrm{C}(/ \mathrm{C}=\mathrm{C} / \mathrm{C}) \mathrm{C}=\mathrm{C} 3\end{array}$ & $\mathrm{CH}=\mathrm{CHCH}_{3}$ & +53.4 \\
\hline III & $\begin{array}{l}\mathrm{O}=\mathrm{C} 2 \mathrm{OC} 1=\mathrm{C}(\mathrm{O}) \mathrm{C}=\mathrm{C}(\mathrm{O}) \mathrm{C}=\mathrm{C} 1 \mathrm{C}=\mathrm{C} 2 \mathrm{C} 3=\mathrm{C} \\
\mathrm{C}=\mathrm{C}(\mathrm{COC}) \mathrm{C}=\mathrm{C} 3\end{array}$ & $\mathrm{COCH}_{3}$ & +65.6 \\
\hline IV & $\begin{array}{l}\mathrm{O}=\mathrm{C} 2 \mathrm{OC} 1=\mathrm{C}(\mathrm{O}) \mathrm{C}=\mathrm{C}(\mathrm{O}) \mathrm{C}=\mathrm{C} 1 \mathrm{C}=\mathrm{C} 2 \mathrm{C} 3=\mathrm{C} \\
\mathrm{C}=\mathrm{C}(\mathrm{C}(\mathrm{OC})=\mathrm{O}) \mathrm{C}=\mathrm{C} 3\end{array}$ & $\mathrm{COOCH}_{3}$ & +67.6 \\
\hline V & $\begin{array}{l}\mathrm{O}=\mathrm{C} 2 \mathrm{OC} 1=\mathrm{C}(\mathrm{O}) \mathrm{C}=\mathrm{C}(\mathrm{O}) \mathrm{C}=\mathrm{C} 1 \mathrm{C}=\mathrm{C} 2 \mathrm{C} 3=\mathrm{C} \\
\mathrm{C}=\mathrm{C}(\mathrm{OC}) \mathrm{C}=\mathrm{C} 3\end{array}$ & $\mathrm{OCH}_{3}$ & +79.6 \\
\hline VI & $\begin{array}{l}\mathrm{O}=\mathrm{C} 2 \mathrm{OC} 1=\mathrm{C}(\mathrm{O}) \mathrm{C}=\mathrm{C}(\mathrm{O}) \mathrm{C}=\mathrm{C} 1 \mathrm{C}=\mathrm{C} 2 \mathrm{C} 3=\mathrm{C} \\
\mathrm{C}=\mathrm{C}(\mathrm{C} \# \mathrm{~N}) \mathrm{C}=\mathrm{C} 3\end{array}$ & $\mathrm{CN}$ & $+68,8$ \\
\hline VII & $\begin{array}{l}\mathrm{O}=\mathrm{C} 2 \mathrm{OC} 1=\mathrm{C}(\mathrm{O}) \mathrm{C}=\mathrm{C}(\mathrm{O}) \mathrm{C}=\mathrm{C} 1 \mathrm{C}=\mathrm{C} 2 \mathrm{C} 3=\mathrm{C} \\
\mathrm{C}=\mathrm{C}([\mathrm{N}+]([\mathrm{O}-])=\mathrm{O}) \mathrm{C}=\mathrm{C} 3\end{array}$ & $\mathrm{NO}_{2}$ & +67.7 \\
\hline VIII & $\begin{array}{l}\mathrm{O}=\mathrm{C} 2 \mathrm{OC} 1=\mathrm{C}(\mathrm{O}) \mathrm{C}=\mathrm{C}(\mathrm{O}) \mathrm{C}=\mathrm{C} 1 \mathrm{C}=\mathrm{C} 2 \mathrm{C} 3=\mathrm{C} \\
\mathrm{C}=\mathrm{C}(\mathrm{Br}) \mathrm{C}=\mathrm{C} 3\end{array}$ & $\mathrm{Br}$ & -64.6 \\
\hline
\end{tabular}

${ }^{1}$ GT probability (equation 1); negative value (no GT) and positive value (GT).

Table 4 shows the QSPR models obtained for each parameter using molecular descriptors from TOPSMODE approach, and the corresponding statisticians. The results showed that three of the four obtained models account for more than $60 \%$ correlation with the GT. 
Table 4. RLM models related to the influence of different thermodynamic parameters on the GT of phenolic compounds.

\begin{tabular}{|c|c|c|}
\hline $\begin{array}{c}\text { Thermodynamic } \\
\text { parameter }\end{array}$ & Model & Statisticians \\
\hline $\begin{array}{l}\text { Principal steric } \\
\text { parameter, } \\
\text { Sterimol (L) }\end{array}$ & $\begin{array}{c}G T=-0,0008 \times L-59.2481 \\
\text { (2) }\end{array}$ & $\begin{array}{c}N=12 ; R=0.622 ; F(1,10) \\
=3.746 ; S_{C V}=12.030 ; p< \\
0.082\end{array}$ \\
\hline $\begin{array}{l}\text { Hydrophobic } \\
\text { parameter, } \\
\text { substituent } \\
\text { constant }(\pi)\end{array}$ & $\begin{array}{c}G T=-7.9742 \times \pi-76.8216 \\
\text { (3) }\end{array}$ & $\begin{array}{c}N=9 ; R=0.653 ; F(1,7)= \\
3.081 ; S_{C V}=13.794 ; p< \\
0.123\end{array}$ \\
\hline $\begin{array}{l}\text { Electronic } \\
\text { parameter, } \\
\text { Hammett } \\
\text { constant }\left(\sigma^{*}\right)\end{array}$ & $\begin{array}{c}G T=3.4782 \times \sigma *-86.3795 \\
\mathbf{( 4 )}\end{array}$ & $\begin{array}{c}N=22 ; R=0.207 ; F(1,20) \\
=0.897 ; S_{C V}=12.010 ; p< \\
0.355\end{array}$ \\
\hline $\begin{array}{l}\text { Global parameter, } \\
\text { partition } \\
\text { coefficient }(\log \mathrm{P})\end{array}$ & $G T=213.435-45.089 \log \mathrm{P}+32.841$ dummy & $\begin{array}{c}N=8 ; R=0.721 ; F(2,5)= \\
2.7091 ; S_{C V}=34.580 ; p< \\
0.159\end{array}$ \\
\hline
\end{tabular}

Regarding the global property analysis ( $\log \mathrm{P})$, which uses a dummy variable representing different groups belonging to the studied compounds, it was shown a correlation over $70 \%$ between GT and lipophilicity. This means that there is a dependence of the studied activity to the hydrophobic character of these compounds. As shown in Equation 5, a decrease in the $\log \mathrm{P}$ is associated with increased DNA damage by clastogenic activity. As it can be seen the GT increased while $\log$ P values decreased. Moreover, the study of the GT is dependent on the subclasses of phenolic compounds (positive value of the dummy variable). This behaviour is similar to that obtained by Sergediene et al. (1999), analysing the influence of lipophilicity in the pro-oxidant nature of a group of polyphenols through QSPR study. It demonstrated experimentally that a decreasing in the lipophilicity was directly related to increased $\mathrm{IC}_{50}$ in leukaemia cells. This helps to explain how morin $(\log \mathrm{P}=1.97)$ and taxifolin $(\log \mathrm{P}=1.22)$, $\operatorname{less}$ soluble than kaempferol ( $\log \mathrm{P}=2.69$ ), are theoretically more "harmful", as observed by the GT values $(66.5,71.3$ and 53.0, respectively). Gallic acid is less soluble (log $\mathrm{P}=0.91)$ and in turn the compound that shows higher probability of GT (97.2). 
From the local modulated properties it was shown that steric (Sterimol, L) and hydrophobic $(\pi)$ properties influence GT activity, but not the electronic parameter (Hammett constant, $\sigma^{*}$ ) as the MTE statisticians shown in Table 4.

From a detailed analysis of local properties, Hansch hydrophobicity constant $(\pi)$ was considered the one that most influenced the activity. As seen in Table 3, the substituent that affected the activity the most was the methoxy group $\left(\mathrm{OCH}_{3}\right)$, a strongly activating group. The thermodynamic parameter "hydrophobicity constant" was the responsible for describing the effects of the lipophilic substituents, which seems to have a better match with strongly activating groups $\left(\mathrm{OH}, \mathrm{OCH}_{3}, \mathrm{NH}_{2}, \mathrm{~N}\left(\mathrm{CH}_{3}\right)_{2}\right)$. In order to demonstrate the relationship between lipophilic character and strength of the substituent, it was conducted a statistical analysis of RLM. This analysis was performed considering two compounds included in the analysed database (biochanin A and genistein), and two compounds that was necessary to generate (with $\mathrm{NH}_{2}$ and $\mathrm{N}\left(\mathrm{CH}_{3}\right)_{2}$ substituents). The results can be seen in Table 5. It was found a high correlation between the GT and the hydrophobicity (and strength) of the substituent ( $\mathrm{R}=94.5 \%)$.

Table 5. Results of RLM taking into account hydrophobicity and Hansch constants.

\begin{tabular}{|c|c|}
\hline Equation QSPR & Statisticians \\
\hline$G T=113.131 \times \pi+58.512$ & $N=4 ; R=0.945 ; R^{2}=0.893 ; F(1,2)=$ \\
(6) & $16.648 ; S_{C V}=30.846 ; p<0.0551$ \\
\hline
\end{tabular}

Substructural level analysis (substituents) indicated that the hydrophobic groups $\left(\mathrm{OCH}_{3}\right)$ have a Hansch constant value of -0.02 [20]. Therefore $\mathrm{OCH}_{3}$ groups contributed more favorably to the activity, assuming the positive value of the constant $\pi$ in the equation 6 . This may be due to increasing the size of the substituent is biggest the possibility of hydrophobic interactions with the carbon chain of n-octanol.

This indicates that the studied properties (global and local) may be correlated. Therefore, it is possible to explain them at substructural level. It is possible to study the influence of the substituent groups or fragments on the lipophilicity, resulting in the relationship between the reported pro-oxidant and clastogenic activity of the studied compounds. 


\section{Conclusions}

QSPR models were obtained for each parameter using molecular descriptors from TOPSMODE approach. The results proved that there is a dependence of the studied activity to the hydrophobic character of these compounds. In addition, a decrease in the $\log \mathrm{P}$ was associated with an increased DNA damage by clastogenic activity. Moreover, the study of the GT was dependent on the subclasses of phenolic compounds. From the local modulated properties it was shown that steric (Sterimol, L) and hydrophobic $(\pi)$ properties influenced GT activity, while the electronic parameter (Hammett constant, $\sigma^{*}$ ) did not. From a detailed analysis of local properties, Hansch hydrophobicity constant $(\pi)$ was considered the one that most influenced the activity. The substituent that most affected the activity was the methoxy group $\left(\mathrm{OCH}_{3}\right)$. In addition, it was found a high correlation between the GT and the hydrophobicity (and strength) of the substituent. In summary, the results allow us to produce an analysis of structure-toxicity relationship in designing strategies for nutraceuticals, functional foods and novel drug with such phenolic compounds on their structure.

\section{References}

1. Azam, S. et al. Prooxidant property of green tea polyphenols epicatechin and epigallocatechin-3-gallate: implications for anticancer properties. Toxicol In Vitro, 2004. 18: p. 555-561.

2. Decker, E.A. Phenolics: prooxidants or antioxidants? Nutr Rev, 1997. 55: p. 396-398.

3. Raza, H. and John, A. Green tea polyphenol epigallocatechin-3-gallate differentially modulates oxidative stress in PC12 cell compartments. Toxicol Appl Pharmacol, 2005. 207: p. 212-220.

4. Watjen, W. et al. Low concentrations of flavonoids are protective in rat H4IIE cells whereas high concentrations cause DNA damage and apoptosis. J. Nutr, 2005. 135: p. 525-531.

5. Procházková, D.I. et al. Antioxidant and prooxidant properties of flavonoids. Fitoterapia, 2011. 82: p. 513-523.

6. Siân, B.A. and Lindsay, D.G. European Research on the Functional Effects of Dietary Antioxidants. Molecular Aspects of Medicine, 2002. 23.

7. Bender, M.A. et al. Mechanisms of chromosomal aberration production III. Chemicals and ionising radiation. Mutat.Res, 1974. 23: p. 197-212.

8. Bello, J. The Science of Health-Promoting Food Products: A Current Panoramic View. Ars Pharm, 2006. 47, 137-171.

9. Yordi, E.G. et al. Antioxidant and pro-oxidant effects of polyphenolic compounds and structure-activity relationship evidence, in Nutrition, Well-Being and Health, J. Bouayed and T. Bohn, Editors. 2012, InTech: Croatia. p. 23-48. 
10. Aruoma, O.I. Methodological considerations for characterizing potential antioxidant actions of bioactive components in plant foods. Mutation Research, 2003. 523: p. 9-20.

11. Breimer, L.H. Molecular Mechanisms of Oxygen Radical Car-cinogenesis and Mutagenesis. The Role of DNA Base Damage. Mol. Carcinog, 1990. 3: p. 188-197.

12. Natarajan, A. Chromosome aberrations: past, present and future. Mutat.Res, 2002. 504 p. 3-16.

13. Yordi, E.G. et al. QSAR study of the potential clastogenic activity of phenolic acids in: 16th International Electronic Conference on Synthetic Organic Chemistry. 2012 [cited 2012 noviembre]; Available from: http://www.sciforum.net/conf/ecsoc16/sections/computational/.

14. Yordi, E.G. et al. Structural alerts for predicting clastogenic activity of pro-oxidant flavonoid compounds: quantitative structure-activity relationship study. J. Biomol. Screen, 2012. 17: p. 216-24.

15. Craig, W. Health-promoting properties of common herbs. Am. J. Clin. Nutr., 1999. 70: p. 491-499.

16. Hansch, C. and Leo, A. Substituent Constant for Correlation Analysis in Chemistry and Biology, ed. Wiley-Interscience. Vol. 339. 1979, New York.

17. Verloop, A. Drugs Design. Vol. V. 1976, New York: Academie Press.

18. Kier, L. General definition of valence delta-values for molecular connectivity. J. Pharm. Sci, 1983.72 p. 1170.

19. Kubinyi, H. Comprehensive Medicinal Chemistry. . Quantitative Drug Design, ed. C. Hansch, P.G. Sammes, and J.B. Taylor. Vol. 4. 1990: Pergamon Press Oxford. 589.

20. Kubinyi, H. QSAR Hansch Analysis and related Approaches, in Parameters in Methods and Principles in Medicinal Chemistry 1993, Mannhold. p. 21.

21. Wold, S.E. Johansson and Cocchi, M. In 3D-QSAR in Drug Design. Theory, Methods and applications, ed. H. Kubinyi1993.: Escom:Leiden. 523.

22. Sergediene, E. et al. Prooxidant toxicity of polyphenolic antioxidants to HL-60 cells: description of quantitative structure-activity relationships. FEBS Letters, 1999. 462: p. 392-396.

23. Fukumoto, L.R. and Mazza, G. Assessing Antioxidant and Prooxidant Activities of Phenolic Compounds. J. Agric. Food Chem, 2000. 48.

24. Pérez Trueba, G. Los flavonoides antioxidantes o prooxidantes. Rev Cubana Invest Biomédicas, 2003. 22.

25. Aruoma, O.I. and Halliwell, B. Pro-oxidant properties: an important consideration for food additives and/or nutrient components?, in Free Radicals and Food Additives 1991, Taylor and Francis: London.

26. Aruoma, O.I. et al. Evaluation of the antioxidant and prooxidant action of gallic acid and its derivatives. J. Agric. Food Chem, 1993. 41: p. 1880-1885.

27. Gow-Chin, Y. and Chiu-Luan, H. Antioxidant Activity of Extracts from Du-zhong (Eucommia ulmoides) toward Various Lipid Peroxidation Models in Vitro. J. Agric. Food Chem, 1998. 46: p. 3952-3957.

28. Müller-Riebau, F. et al. Chemical composition and fungitoxic properties to phytopathogenic fungi of essential oils selected aromatic plants growing wild in Turkey. J. Agric. Food Chem, 1995. 43: p. 2262-2266. 
29. Kupidlowska, E. et al., Influence of methyl derivatives of coumarin on mitotic activity and ultrastructure of meristematic cells of Allium cepa root tips. Phytomedicine, 1996. 2: p. 275-281. 